\title{
Application Of Principles Of Total Quality Management (TQM) In Teacher Education Institutions
}

M. Manivannan, Tamil Nadu Open University, India

K. S. Premila, Tamil Nadu Open University, India

\begin{abstract}
The indomitable spirit of higher education paves the way for the growth of a nation in the political, economic, social, intellectual and spiritual dimensions. Teacher education is one of the areas in higher education which trains student-teachers in pedagogy, which in turn helps them to train the young minds of educational institutions. The "Fate of the nation is decided in the classroom," is a remark made by the Education Commission of India. Such classrooms are created by committed and dedicated teachers. These teachers are trained in teacher education institutions. Teacher education institutions should maintain quality to ensure the academic excellence of trainees who come into the teaching profession. Quality is a comparative standard prescribed for those institutions that are on the quest for output brilliance. Quality assurance in teacher education reflects on the high profile of the institution and the competency of student-teachers. The present study on the application of principals of TQM in teacher education institutions in India has exposed the tangibility of institutions in the perception of teachers based on eleven quality indicators, such as principal as leader, teacher quality, linkage and interface, students, co-curricular activities, teaching, office management, relationships, material resources, examinations and job satisfaction. A total of nine colleges of education was selected to collect data. The exploratory technique under the survey method of research design was used for the study. A tool - 'Teacher Institutional Profile' (TIP) - was constructed, standardized and used for data collection. Quantitative and qualitative analyses were made for finding and interpreting results. The findings focus on the strong and weak areas of various teacher education institutions according to the quality indicators. The study recommends further strengthening of quality indicators, which are already strong, and the revamping of weaker quality indicators. It is also recommended that institutions should adhere to the quality standards set by national and international assessment and accreditation bodies. In conclusion, the global scenario expects skilled teachers to produce students with a versatile personality for which teacher education should be strengthened.
\end{abstract}

Keywords: Total Quality Management (TQM), Teachers Institutional Profile (TIP), Government, Government Aided, Self-financing, Quality Indicators

\section{INTRODUCTION}

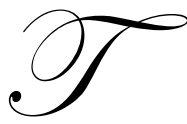

otal quality Management (TQM) has gained wide acceptance in the business world as an institutional transformation philosophy. During the last two decades, it has claimed the attention of scholars and practitioners as a 'paradigm worth considering' for managing higher education. While accepting the successes of TQM in business and industry, it is worth noting that the barriers to implementing TQM in education are the same as those experienced in the industry and the health care sector.

The report of Indian Education Commission (1964-66) states, "The destiny of India is being shaped in classrooms. The most important and urgent reform needed in education is to transform it, to endeavour to relate it to the life, needs and aspirations of the people, and thereby make it a powerful instrument of social change necessary 
for the realization of national goals." The reforms in teacher education are necessary to achieve national goals. For this purpose, education should be developed so as to increase productivity, achieve social and national integration, strengthen democracy, accelerate the process of modernization and cultivate social, moral and spiritual values. The national goals cannot be achieved without educational development. Teacher education has a significant role to play in maintaining the quality of education. Quality management is not an overnight process and it is not the product of a single hand.

At present, a wide range of organizations are involved in what is commonly referred to as Total Quality Management (TQM) Implementation, and associated research has primarily been focused in the business community. However, over the past decade, faced with dwindling enrollment and increased competition, the educational community has also started to embrace TQM at differing levels in a wide variety of settings across the nation, ranging from higher research institutions to elementary schools.

Higher education lays significant emphasis on human capital formation. It produces intellectual leaders and path makers. No nation can go high without quality higher education. Basically, primary and secondary levels of education are concerned with transfer of knowledge from the teacher to the taught. But higher education involves analysis, synthesis and the transformation of information into knowledge. Teachers in higher education are to be involved not only in teaching, but also in making good citizens of the country. Quality in higher education is becoming an important issue for research and discussion, and there is abundance of literature on this issue. With this in mind, the investigator was motivated to select a problem in quality management. Since the concept of total quality management is becoming popular among developing and developed countries in the world today, a study of the application of total quality management in teacher education institutions is appropriate and relevant.

\section{Total Quality Management in Education}

The Gurukula System of education was probably the best example of quality management in education. In the Gurukula (Gurukula means Preceptor's family) system, students lived with the Guru in his family until the time they completed their study. The Gurukula tradition of total quality was successfully transferred to the early Indian Universities like Nalanda and Takshasila.

The expertise of visionaries also in institutional planning should be a part of planning the academic curriculum. The Concept of Total Quality Management should not be left to the corporate world. It should extend its reach to educational institutions too. Now some computer education institutions have obtained ISO 9001 to assure their clientele ( the learners enrolling in their institutions) of quality education. This phenomenon should be extended to schools, colleges and universities. The governing body awarding accreditation should review the status of institutions periodically to ensure quality-learning.

Quality Education in schools and colleges will lead to qualified human resources moving to higher education and in their producing highly qualified manpower for demanding careers (Barnett, 1994). Once appointed in colleges in government scale of pay, there is stagnation in the teachers' growth and development. The teaching community should not be come complacent with the belief that experience alone would suffice to carry on their work effectively. Myron Tribus has often said, "Experience alone teaches nothing. If you do not have a theory to provide a framework to understand your experience, you do not accumulate thirty years of experience; you merely repeat one year thirty times" (Myron Tribus 1994 quotes in W.Edwards Deming).

\section{TQM Theory and Principles}

Philosophy, Vision, Strategy, Skills, Resources, Rewards and Organisation are the principles of total quality management (Myron Tribus, 1994). Many people have their own definition of quality and restrict the concept of quality to some sectors only. Education is an obligation and quality should extend its reach to the Education Diaspora. The concept of quality instruction goes above and beyond innovation. It is not that we do not know how to make learning more innovative and joyful. We do. It is that we need to design educational experience that will deliver predictable learning. Success can come from thinking about acting strategically to define, design and deliver quality instruction. Teachers should design Quality Instruction Planning Programme to optimize learning 
situations. They have to define, design and deliver educational experiences in the context of quality provided the instruction is innovative and will be useful for the target learner. The learning experience should be rewarding, leading to life-long learning, so that the learners learn where and when to use them effectively to empower themselves (Kaufmanns and Zahn, 1993). When applying TQM principles to learning, care should be taken to give due importance to all the above principles. The omission of any one in this chain renders the theory inoperable since all are interlinked.

\section{Philosopy: Inspiration}

The presence of sound philosophy leads to inspiration but in the absence of philosophy, there are no followers. Application of TQM principles to classroom teaching will inspire the learners, which will lead them to adopt a similar methodology in their future assignments.

\section{Vision: Life-Long Learning}

A good vision leads to life-long learning while the absence of vision may lead to confusion. This is a longterm benefit that a learner will enjoy. Lifelong learning is an important aspect in one's life. Any course or degree should not be considered an end to learning. The teacher should be a visionary in inculcating a passion for life long learning in the learners.

\section{Strategy: Learning Skills}

The presence of a sound strategy leads to developing learning skills; otherwise there will be a problem from the very beginning. To achieve the objectives of learning and to have the desired learning outcomes, it is necessary to devise the learning instruction in such a way that learners learn to learn. Developing learning skills are very important not only to accomplish the immediate course or degree requirement but also to imbibe the quality to learn.

\section{Skills: Holistic Approach}

Presence of good skills leads to a holistic approach but in the absence of skills there is anxiety. A holistic approach to learning ensures quality in education and makes learning a pleasure and joy. The attachment to learning should be healthy. It requires dedication and commitment to facilitate self-directed learning.

\section{Resources: Maximum Usage of Available Resources and Facilities}

The availability of appropriate resources leads to optimum usage of available resources and facilities. The absence of resources leads to frustration among both learners and teachers. Before going in for procuring new resources and facilities for facilitating the process of innovative teaching and practice, the existing resources should be used in an optimum manner. Instead of wasting precious time, money and energy, a teacher should use the available resources.

\section{Rewards: Desired Learning Outcomes}

The presence of suitable rewards leads to desired learning outcomes. In the absence of rewards, there is bitterness. Rewards and recognition for innovative teaching leads to the desired learning outcomes. The following are some of the rewards that can motivate the teachers

- $\quad$ Completion of units of the course in an innovative way.

- Involvement of all learners in the learning process.

- $\quad$ Recognition from learners, colleagues and the head of the institution.

- $\quad$ Benefit from teamwork and learning the art of working as a team.

- $\quad$ Different learning environments resulting in development of leadership qualities.

- Co-operative and collaborative learning.

- Recognition and appreciation of peers. 
- $\quad$ Appreciation for the learning experience.

Organisation: Cooperation of Support Services

For any innovative experiment to be successful, the co-operation of both the teaching and the non-teaching staff of the educational institution are necessary. In the absence of organization, there is no co-operation of support services which hinders organized learning.

\section{Concept of Customer in Higher Education}

Universities have a variety of customers. One definition of customer is that of "a buyer of a product or service." Students attend classes, consume meals, sleep in residence halls, buy books and use many services for which they pay fees. The student certainly fits this definition of the word customer. The businesses and professions that employ the graduate are also customers, as is the general public.

Universities have an almost infinite variety of internal customers as well. Internal customers of a service are those individuals or entities whose product or service depends on that service. For example, the payroll department is a customer of the computer centre because without the computer and the computer centre the payroll does not get produced. The Dean's office is a customer of the accounting department because the dean's office needs timely, accurate financial information to make appropriate decisions.

Most frequently, external customers have the freedom to choose their supplier, and in fact, do so. This is, for the most part, not true for internal customers. They do not have a choice.. They must use their service provider, because it is their only option. This lack of competition frequently breeds contempt for internal customers. When one begins to treat a person or entity as an external customer, one's attitude towards that person or entity changes. A customer is vital to the survival of the organization. The Customer can choose another supplier if the quality of the service or the product is inferior or deteriorates.

One of the most important aspects of the TQM - focused organisation is that departments begin to treat other departments as important customers by trying to meet the customer's needs and time schedules. This simple concept has an absolutely revolutionary effect on the relationships that exist within a traditional organization.

The idea of the student being the customer of a professor is a concept that takes many faculty members take a while to assimilate. Certainly the student and faculty relationship is far more complex than that of a simple customer-supplier relationship. Yet, clearly one dimension of this relationship involves the student as customer. The student is buying the professor's course and has the unmistakable right to expect certain things for his or her money; relevant course content, fairness, access, expertise, and a reasonable learning situation. If a faculty member views the student as a customer, it is likely that the faculty member will become more tolerant, more interested in implementing ways to improve the learning process, more accessible, and more student-friendly. Many faculty members say that the student is not the customer, but is the product. However, upon closer review, it becomes evident that the student is not the product; the product is the learning of the students. Learning is a team effort between the professor and the student. Jointly, they produce a product-the learning of the student. Both parties are reasonable participants in that process.

\section{The Pillars of Quality}

Total quality management in any organisation is supported by four driving forces, or pillars, that move the organisation toward the full application of quality service. The four pillars of the House of Quality are customer service, continuous improvement, managing with facts and respect for people. All are distinct, but equal in potential strength. All four must be addressed, minimizing one weakens the others. By not addressing one, the entire House of Quality will fall. 


\section{Serving the Customer}

College and University enrolments have not diminished substantially over the past three decades; every college and university has a mission, but very few fully identify who they serve. Even fewer acknowledge that they serve customers. While viewing the campus as a customer-driven entity may be anathema to many; one truth has been proven repeatedly: customer-driven organizations are effective because they focus on a full commitment to satisfying, even anticipating, the needs of the customer. While colleges and universities have been successful, their future success will increasingly be determined by customer satisfaction. Those campuses that are successful will be those that most clearly identify their mission and the customer-driven organizations are successful because they have a unified focus on what they do and who they serve.

\section{Continuous Improvement}

Continuous Improvement is both a commitment and a process. The commitment to quality is initiated with a statement of dedication to a shared mission and vision and the empowerment of all participants to incrementally move toward the vision. The process of improvement is accomplished through the initiation of small, short-term projects and tasks throughout the organisation, which collectively are driven by the achievement of the long-term vision and mission. Both are necessary; one cannot be done without the other.

\section{Managing with Facts}

This requires a substantial shift in many areas of higher education to a process of carrying out continuous improvement and effective process management through the extensive use of a variety of tools designed to gather and analyse data and make decisions based on facts.

\section{Respect for People}

The output of colleges and universities is teaching, service, and research. It also encompasses the quality of life of every one who works in, or is affected by, the college or university. Fortunately, quality of output goes handin-hand with quality of work. The only way total quality will be attained is through total commitment and participation.

\section{OBJECTIVES OF THE STUDY}

The following are the objectives of the present study:

1. To study the application of principles of Total Quality Management (TQM) in Teacher Education Institutions.

2. To analyse the Institutional profile based on the perception scores of teachers on quality indicators.

3. To investigate the effect of independent variables; namely, gender, locality and years of experience, on input indicators.

4. To find out the teachers' perceptions on process and product indicators.

5. To focus the recommendations derived based on the findings of the study.

\section{RESEARCH METHODOLOGY}

\section{Sample}

A total of 9 Colleges of Education was taken for selecting the sample for the present study. Of 9 Colleges of Education, 3 were Government institutions, 3 Government Aided Institutions and 3 Self-Financing Institutions. A total of 50 teachers were selected as a sample from 86 teachers in the colleges of education through random sampling technique. 


\section{Variables}

The investigators used 1) Gender 2) Locality and 3) Experience as the independent Variables. 'Perception' is the dependent Variable for the study.

\section{Research Design}

The primary aim of this study was to identify strengths and weaknesses of the various institutions on the basis of quality indicators. Therefore, descriptive and survey method were used in the present study.

\section{Tools and Statistical Procedure}

The standardised tool viz., Teacher's Institutional Perception Scale (TIPS) was used for collecting the data from the teachers of colleges of education. This tool consists of 132 statements, which were answered based on a five point scale - Strongly Agree, Agree, Not Sure, Disagree and Strongly Disagree.

Quantitative Analysis was made for the data collected through the perception scale. Analysis of Variance (ANOVA) was used for interpreting the results of the perception scores of teachers on total quality management.

\section{FINDINGS DERIVED FROM DATA ANALYSIS}

\section{Analysis of Institutions Based on Quality Indicators}

The investigator classified the teacher education institutions into various types, such as Government, Government-Aided and Self-financing. The strengths and weaknesses of each institution (organizational profile) were carefully analysed against the average perception scores of the teachers in the following 11 areas of quality indicators:

1. Leadership

2. Teacher quality emphasizing teacher preparation, teaching competency and teacher commitment

3. Linkage and interface through communication with environment

4. Quality of students with respect to academic and non-academic traits

5. Co-curricular activities related to all non-scholastic areas

6. Quality of instruction

7. Office management as support services

8. Establishing relationship with corporate life of the institution

9. Material resources utilized for institutional support

10. Conduct of examinations with specific purpose using appropriate methodology

11. Sustaining staff morale through ensuring job satisfaction

Table 1: Analysis of the Teachers Institutional Profile (TIP)

\begin{tabular}{|c|c|c|c|c|c|c|c|}
\hline \multirow[b]{2}{*}{ S.No. } & \multirow[b]{2}{*}{ Quality Indicators } & \multicolumn{2}{|c|}{ Government } & \multicolumn{2}{|c|}{ Government-Aided } & \multicolumn{2}{|c|}{ Self-financing } \\
\hline & & $\begin{array}{c}\text { Scores } \\
<1.67 \\
\end{array}$ & $\begin{array}{c}\text { Scores } \\
>1.67 \\
\end{array}$ & $\begin{array}{l}\text { Scores } \\
<6.94 \\
\end{array}$ & $\begin{array}{l}\text { Scores } \\
>6.94 \\
\end{array}$ & $\begin{array}{l}\text { Scores } \\
<4.52 \\
\end{array}$ & $\begin{array}{l}\text { Scores } \\
>4.52 \\
\end{array}$ \\
\hline 1. & Principal as Leader & & 4.96 & & 11.24 & & 10.45 \\
\hline 2. & Teacher Quality & & 4.1 & & 7.75 & & 6.2 \\
\hline 3. & Linkage and Interface & & 2.18 & 5.42 & & 2.34 & \\
\hline 4. & Students & & 3.6 & & 9.23 & 4.09 & \\
\hline 5. & Co curricular Activities & 1.42 & & & 8.22 & 2.38 & \\
\hline 6. & Teaching & & 3.9 & & 7.63 & & 5.22 \\
\hline 7. & Office Management & & 4.4 & & 8.11 & & 5.66 \\
\hline 8. & Relationships & 1.09 & & 5.81 & & & 7.11 \\
\hline 9. & Material Resources & 1.31 & & & 7.3 & & 8.32 \\
\hline 10. & Examinations & & 5.2 & & 8.85 & 3.86 & \\
\hline 11. & Job Satisfaction & & 6.3 & 4.94 & & 2.96 & \\
\hline
\end{tabular}


Table 2: Stronger and Weaker Areas of Various Institutions

\begin{tabular}{|c|c|c|c|}
\hline S.No & Institutions & Stronger & Weaker \\
\hline 1. & Government & $\begin{array}{l}\text { Principal as Leader } \\
\text { Teacher Quality } \\
\text { Linkage and Interface } \\
\text { Students } \\
\text { Teaching } \\
\text { Office Management } \\
\text { Examinations } \\
\text { Job Satisfaction }\end{array}$ & $\begin{array}{l}\text { Co-curricular Activities } \\
\text { Relationships } \\
\text { Material Resources }\end{array}$ \\
\hline 2. & Government-Aided & $\begin{array}{l}\text { Principal as Leader } \\
\text { Teacher Quality } \\
\text { Students } \\
\text { Co-curricular Activities } \\
\text { Teaching } \\
\text { Office Management } \\
\text { Material Resources } \\
\text { Examinations }\end{array}$ & $\begin{array}{l}\text { Linkage and Interface } \\
\text { Relationships } \\
\text { Job Satisfaction }\end{array}$ \\
\hline 3. & Self-financing & $\begin{array}{l}\text { Principal as Leader } \\
\text { Teacher Quality } \\
\text { Teaching } \\
\text { Office Management } \\
\text { Relationships } \\
\text { Material Resources }\end{array}$ & $\begin{array}{l}\text { Linkage and Interface } \\
\text { Students } \\
\text { Co-curricular Activities } \\
\text { Examinations } \\
\text { Job Satisfaction }\end{array}$ \\
\hline
\end{tabular}

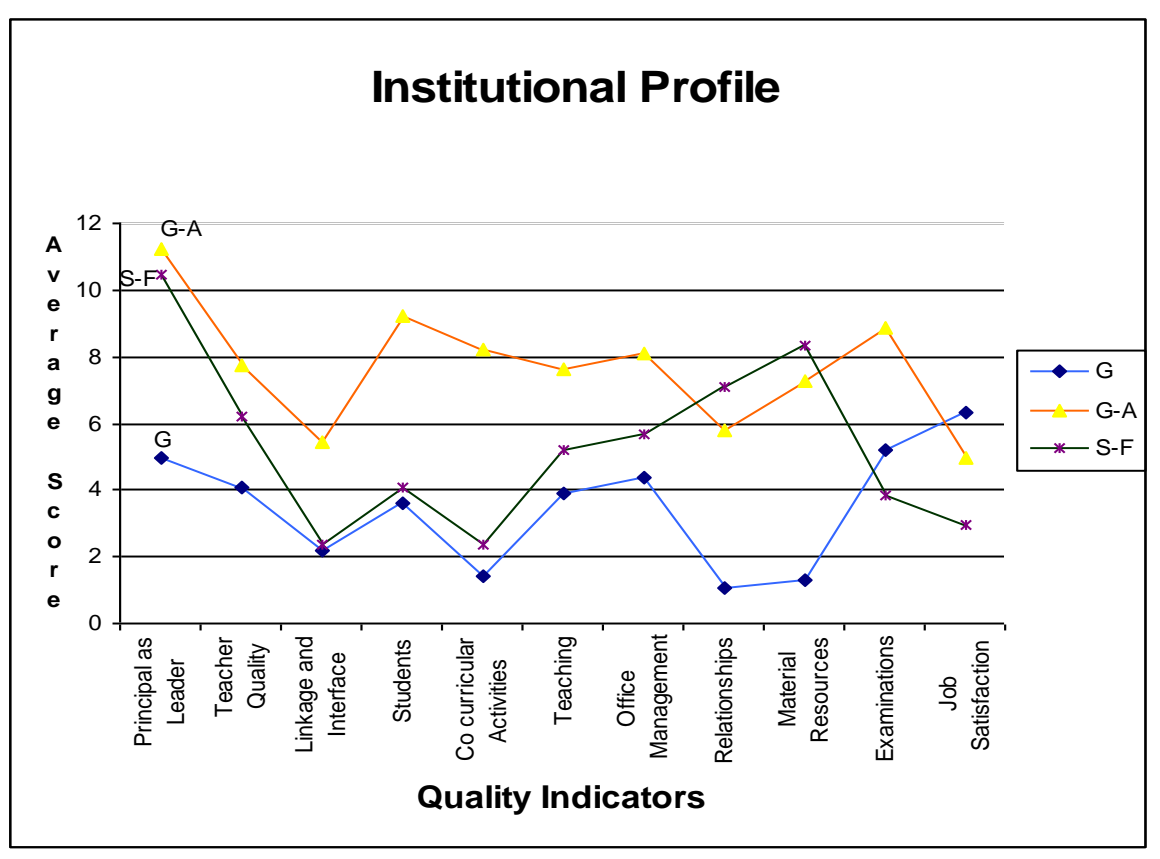

Figure1: Institutional Profile

Tables 1 and 2 indicate that in Government institutions, the areas, such as Principal as Leader, Teacher Quality, Linkage and Interface, Students, Teaching, Office Management, Examinations, and Job Satisfaction, were identified as stronger areas since the institutional average score stands well above the cut-off point of 1.67. The areas, such as Co-curricular Activities, Relationships, and Material Resources, falling below the institutional average were identified as weaker areas. 
Tables 1 and 2 indicate that in Government-Aided institutions, the areas, such as Principal as Leader, Teacher Quality, Students, Co-curricular Activities, Teaching, Office Management, Material Resources, and Examinations were identified as stronger areas since the institutional average score stands well above the cut-off point of 6.94. The areas such as Linkage and Interface, Relationships, and Job Satisfaction, falling below the institutional average, were identified as weaker areas.

Tables 1 and 2 indicate that in Self-financing institutions, the areas, such as Principal as Leader, Teacher Quality, Teaching, Office Management, Relationships, and Material Resources, were identified as stronger areas since the institutional average score stands well above the cut-off point of 4.52. The areas such as Linkage and Interface, Students, Co-curricular Activities, Examinations, and Job Satisfaction falling below the institutional average, were identified as weaker areas.

The graphical representation of the various institutions on the quality indicators is presented in Figure 1.

\section{Analysis Based on the Types of Quality Indicators}

In Total Quality Management (TQM), the quality indicators are classified in Figure 2.

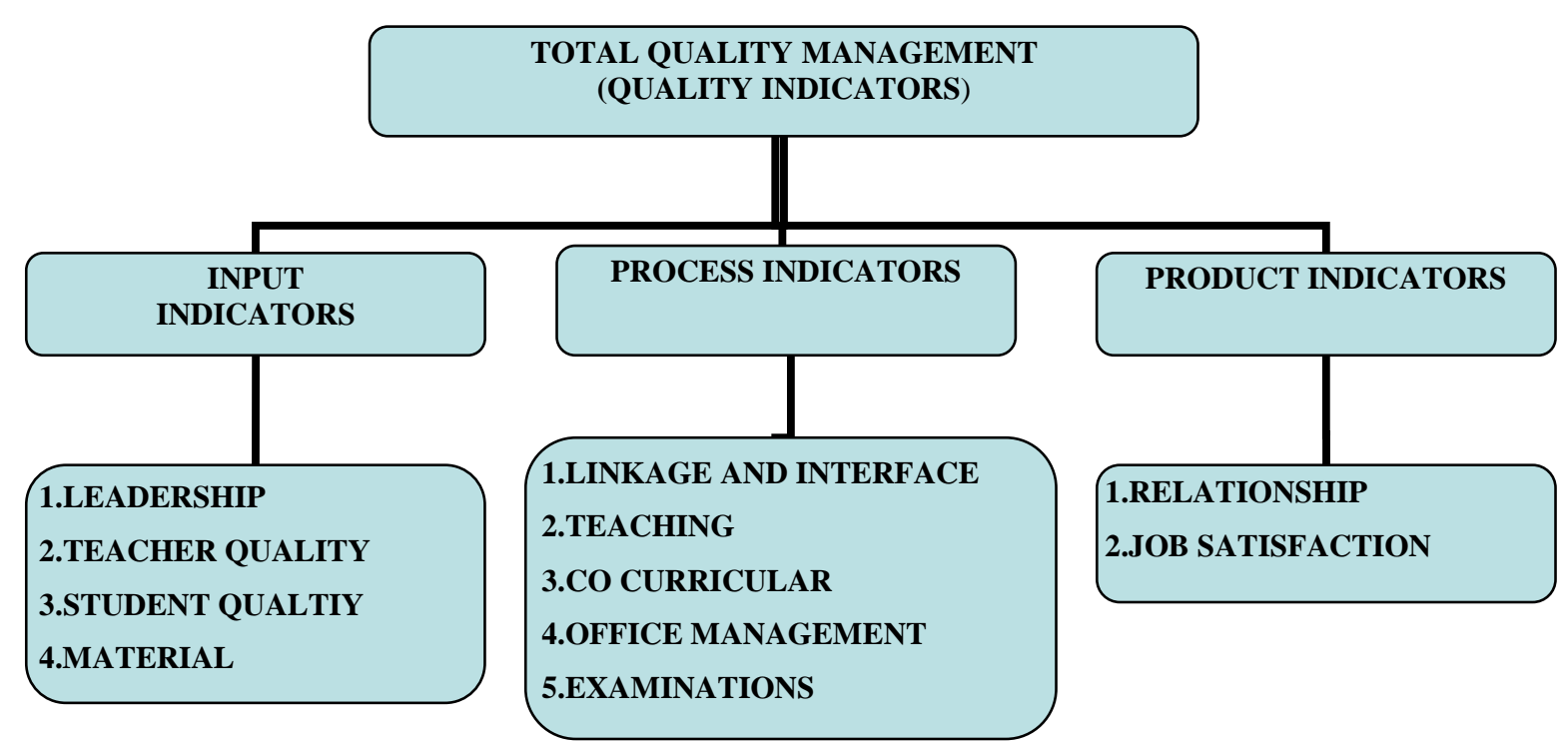

Figure 2 TQM Classification

\section{Analysis of Data Collected Using Teachers' Institutional Profile Scale (TIPS) on Input Indicators in Terms of Gender, Locality and Experience}

A three-way analysis of variance technique was employed to investigate the effect of independent variables; namely, gender, locality and years of experience on the scores of teachers collected through TIPS in the dependent variables 'input indicators'. The results of ANOVA for the teachers' perception scores on input indicators are presented in Table 3. 
Table 3: Results of ANOVA on the "Input Indicators" of TIPS

\begin{tabular}{|l|c|c|c|c|}
\hline \multicolumn{1}{|c|}{ Source } & Sum of Squares & df & Mean Square & F \\
\hline Gender (A) & 63.441 & 1 & 63.441 & $0.124^{* * *}$ \\
\hline Locality (B) & 1370.920 & 1 & 1370.920 & $2.685^{* * *}$ \\
\hline Experience(C) & 1150.231 & 2 & 575.115 & $1.127^{* * *}$ \\
\hline A X B & 563.979 & 1 & 563.979 & $1.105^{* * *}$ \\
\hline A X C & 78.906 & 2 & 39.453 & $0.077^{* * *}$ \\
\hline B X C & 590.786 & 2 & 295.393 & $0.579 * * *$ \\
\hline A X B X C & 427.227 & 2 & 213.614 & $0.418^{* * *}$ \\
\hline Residual (Error) & 62282.193 & 122 & 510.510 & \\
\hline
\end{tabular}

$* * *$ no significant difference

Table 3 proves the following null hypotheses to be tenable:

Null hypothesis 1: "There is no significant difference between the mean perception scores of teachers on the input indicators as per gender".

Null hypothesis 2: "There is no significant difference between the mean perception scores of rural and urban teachers on the input indicators as per locality".

Null hypothesis 3: "There is no significant difference between the mean perception scores of teachers on the input indicators as per the experience of teachers".

Further, the interaction effect on the scores of teachers on the input indicators as per the variables gender and locality (A X B), gender and experience (A X C), locality and experience (B X C) and the gender, locality and experience (A X B X C) revealed that F values (Interaction Effects) are less than that of the table value and so it is interpreted that there is no significant in the mean perception scores of teachers on the input indicators.

\section{Analysis of Data Collected Using Teachers' Institutional Profile Scale (TIPS) on Process Indicators in Terms of Gender, Locality and Experience}

A three-way analysis of variance technique was employed to investigate the effect of independent variables, namely, gender, locality and years of experience on the scores of teachers collected through TIPS in the dependent variables 'Process indicators'. The results of ANOVA for the teachers' perception scores on process indicators are presented in the following table.

Table 4: Results of ANOVA on the "Process Indicators" of TIPS

\begin{tabular}{|l|c|c|c|c|}
\hline \multicolumn{1}{|c|}{ Source } & Sum of Squares & df & Mean Square & F \\
\hline Gender (A) & 62.955 & 1 & 62.955 & $0.070^{* * *}$ \\
\hline Locality (B) & 1738.471 & 1 & 1738.471 & $1.932^{* * *}$ \\
\hline Experience(C) & 481.945 & 2 & 240.973 & $0.268^{* * *}$ \\
\hline A X B & 214.478 & 1 & 214.478 & $0.238^{* * *}$ \\
\hline A X C & 428.026 & 2 & 214.013 & $0.238^{* * *}$ \\
\hline B X C & 85.278 & 2 & 42.639 & $0.047^{* * *}$ \\
\hline A X B X C & 774.266 & 2 & 387.133 & $0.430^{* * *}$ \\
\hline Residual (Error) & 109775.968 & 122 & 899.803 & \\
\hline
\end{tabular}

*** no significant difference

Table 4 shows the following null hypotheses are tenable:

Null hypothesis 1: "There is no significant difference between the mean perception scores of teachers on the process indicators as per gender". 
Null hypothesis 2: "There is no significant difference between the mean perception scores of rural and urban teachers on the process indicators as per locality".

Null hypothesis 3: "There is no significant difference between the mean perception scores of teachers on the process indicators as per the experience of teachers".

Further, the interaction effect on the scores of teachers on the process indicators as per the variables gender and locality (A X B), gender and experience (A X C), locality and experience (B X C) and the gender, locality and experience (A X B X C) revealed that F values (Interaction Effects) are less than that of the table value and so it is interpreted that there is no significant difference in the mean perception scores of teachers on the process indicators.

\section{Analysis of Data Collected Using Teachers' Institutional Profile Scale (TIPS) on Product Indicators in Terms of Gender, Locality and Experience}

A three-way analysis of variance technique was employed to investigate the effect of independent variables namely gender, locality and years of experience on the scores of teachers collected through TIPS in the dependent variables 'product indicators'. The results of ANOVA for the teachers' perception scores on product indicator are presented in the following table.

Table 5: Results of ANOVA on the "Product Indicators" of TIPS

\begin{tabular}{|l|c|c|c|c|}
\hline \multicolumn{1}{|c|}{ Source } & Sum of Squares & df & Mean Square & F \\
\hline Gender (A) & 37.884 & 1 & 37.884 & $0.359^{* * *}$ \\
\hline Locality (B) & 467.424 & 1 & 467.424 & $4.432^{*}$ \\
\hline Experience(C) & 632.877 & 2 & 316.438 & $3.000^{* * *}$ \\
\hline A X B & 7.593 & 1 & 7.593 & $0.072^{* * *}$ \\
\hline A X C & 23.200 & 2 & 11.600 & $0.110^{* * *}$ \\
\hline B X C & 57.207 & 2 & 28.603 & $0.271^{* * *}$ \\
\hline A X B X C & 76.500 & 2 & 38.250 & $0.363^{* * *}$ \\
\hline Residual (Error) & 12867.814 & 122 & 105.474 & \\
\hline
\end{tabular}

*significance at 0.05 level *** no significant difference

Table 5 showed that the null hypotheses $1 \& 3$ are tenable while null hypotheses 2 is rejected.

Null hypothesis 1: "There is no significant difference between the mean perception scores of teachers on the product indicators as per gender" is tenable.

Null hypothesis 2: "There is no significant difference between the mean perception scores of rural and urban teachers on the product indicators as per locality" is rejected.

Null hypothesis 3: "There is no significant difference between the mean perception scores of teachers on the product indicators as per the experience of teachers" is tenable.

Further, the interaction effect on the scores of teachers on the product indicators as per the variables gender and locality (A X B), gender and experience (A X C), locality and experience (B X C) and the gender, locality and experience (A X B X C) revealed that F values (Interaction Effects) are less than that of the table value and so it is interpreted that there is no significant difference in the mean perception scores of teachers on the product indicators.

\section{RECOMMENDATIONS}

The findings of the study have many implications on maintaining the total quality in teacher education institutions. It has implications on quality development of teacher education, teachers' job satisfaction and linkage with community, focus on leadership quality of the principal, experience of the teachers on TQM. The following recommendations are put forth by the investigator for necessary follow-up and further research pursuit. 


\section{Quality Development of Teacher Education}

Teacher education comes under higher education. Higher education plays a vital role in human capital formation. Economic development of a country is also correlated with the development of higher education, says the World Bank (1998). In any educational programme, the teacher is the most important element. Adequate number of quality teachers can implement the educational process through which the desired development of the students is achieved. The quality of the teacher, to a large extent, depends on the quality of teacher education received by him/her (NCTE, 1998). The following recommendations are made in order to ensure the quality in teacher education programme.

1. All teacher education institutions should ensure that quality management is implemented at all levels. These institutions should be subjected to periodical assessment and accreditation from the national assessment bodies like NAAC and ISO.

2. Internal and external periodical assessment cells should be formed to monitor and promote quality in teacher education programmes as per the guidelines of national agencies like National Council for Teacher Education (NCTE), NAAC etc.

3. Establishment of teacher education institutions should be according to the demand and supply policy. Quality of teacher education should be ensured when there is quantitative expansion.

\section{Teachers' Job Satisfaction and Linkage with Community}

The present study found that most of the teachers in Government aided institutions and self financing institutions, though they maintained quality in teaching, did not have job satisfaction. As a result, they didn't attempt to contribute more to improving the linkage with community. The following strategies should be worked out to enhance the job satisfaction of the teachers and their linkages with community.

1. The management and the head of the institution should have frequent interaction with the teachers to understand their needs.

2. More opportunities for professional development must be provided.

3. Transparent administration would certainly enhance quality improvement.

4. Teachers are to be given assignments to go with the community to conduct extension service activities such as awareness camps, campaigns, parents meet, and social gatherings. Community participation in institutional activities will strengthen the teachers' linkage with community.

\section{Focus on Leadership Quality of the Principal}

The present study clearly indicated that the principal as leader is stronger area in all types of institutions such as government and government aided and self-financing institutions. The following recommendation can further strength this area. The leader of the institution needs to possess important qualities such as leadership, manager, administrator and researcher.

\section{CONCLUSION}

Several research studies conducted in the field of education reveal that total quality management has significant implications in education. Very limited number of studies are available/have been conducted on the application of TQM in teacher education. Therefore an attempt was made in this study to see that to what extent the principles of TQM could be applied in the area of Teacher Education. The present study provides many insights into how institutions can train efficient teachers through quality teacher education institutions.

\section{AUTHOR INFORMATION}

Dr. K.S. Premila is Assistant Professor at Tamil Nadu Open University, Chennai, India. She holds doctoral degree in Education. She involves in Teaching, Research and Extension activities related to Mathematics and Computer Education. She has prepared self-instructional course materials for Bachelor of Education. She monitors the 
Program Study Centres of Bachelor of Education in Special Education. She has also served as a principal for the College of Education. She has attended many national and International conferences and presented papers. She published several research articles in the leading journals in India.

Dr. M. Manivannan, Ph.D. is Head of the School of Education at Tamil Nadu Open University, Chennai, India. He has 15 years of teaching and administrative experience in the field of education. He has served as a Deputy Director for International Human Resource Development Centre for the Disabled (IHRDC). He is a member of the Rehabilitation Council of India, a body of professionals dealing with visual impairment. He has published books on Psychology, Special Education, Guidance and Counseling. He has attended several national and International conference and presented papers. He has over 30 publications to his credit.

\section{REFERENCES}

1. Baas, Alvin G.(1995). Quality Service Indicators and their Importance to Student Satisfaction in Selected Community Colleges (Total Quality Management). University of Minnesota.

2. Carroll, Timothy Warren. (1994). Total Quality Management in Higher Education: Implementation and Barriers. University of Central Florida.

3. Lawis, R.G and Smith, D.H (1994). Total Quality in Higher Education. Floria: St.Lucie Press.

4. Moore, A.J. (1996) Improving Schools. Quality Indicators used when Selecting K-12 Teachers. Kanas:

Emporia State University 